Article

\title{
Joining Technologies for Automotive Battery Systems Manufacturing
}

\author{
Abhishek Das * (D), Dezhi Li, David Williams and David Greenwood \\ WMG, The University of Warwick, Coventry CV4 7AL, UK; Dezhi.Li@warwick.ac.uk (D.L.); \\ David.K.Williams@warwick.ac.uk (D.W.); D.Greenwood@warwick.ac.uk (D.G.) \\ * Correspondence: a.das.1@warwick.ac.uk; Tel.: +44-247-657-3742
}

Received: 13 June 2018; Accepted: 3 July 2018; Published: 5 July 2018

check for updates

\begin{abstract}
An automotive battery pack for use in electric vehicles consists of a large number of individual battery cells that are structurally held and electrically connected. Making the required electrical and structural joints represents several challenges, including, joining of multiple and thin highly conductive/reflective materials of varying thicknesses, potential damage (thermal, mechanical, or vibrational) during joining, a high joint durability requirement, and so on. This paper reviews the applicability of major and emerging joining techniques to support the wide range of joining requirements that exist during battery pack manufacturing. It identifies the advantages, disadvantages, limitations, and concerns of the joining technologies. The maturity and application potential of current joining technologies are mapped with respect to manufacturing readiness levels (MRLs). Further, a Pugh matrix is used to evaluate suitable joining candidates for cylindrical, pouch, and prismatic cells by addressing the aforementioned challenges. Combining Pugh matrix scores, MRLs, and application domains, this paper identifies the potential direction of automotive battery pack joining.
\end{abstract}

Keywords: EV (electric vehicle); thin metal film; electrode; materials; powertrain; joining

\section{Introduction}

Recent advances in developing secondary batteries enables their extensive use in everyday life, from portable technologies to high energy applications. Lithium-ion based secondary batteries show enormous potential to be used for low to high capacity applications, such as portable electronics and electric vehicles, respectively. High energy density, low self-discharge, and portability characteristics of Li-ion based automotive battery packs make them an emerging alternative power source that are being increasingly used in electric vehicles (EVs), hybrid or plug-in hybrid electric vehicles (HEVs or PHEVs) [1-3]. Often, these vehicles are exposed to different driving conditions having a huge impact on the energy consumption [4]. Typically, a standard automotive battery pack consists of hundreds, even thousands, of individual Li-ion batteries that are connected in series or parallel in order to achieve the required power and energy. Additionally, there is an increasing requirement for manufacturing of battery packs, reflecting the increased demand for this energy storage technology, which is predicted to grow as the volume of automotive product using it develops.

In general, an automotive battery pack can be hierarchically decomposed into three levels: (a) emphcell level: an individual battery cell is primarily composed of positive and negative electrodes, separators, electrolyte, and case; (b) module level: a collection of multiple cells generally connected in series and parallel, encased in a mechanical structure; and (c) pack level: a battery pack is assembled by connecting modules together, either in series or parallel, with sensors and controllers, and then is encased in a housing structure. Typically, design and construction of an automotive Li-ion battery pack, as illustrated in Figure 1, involve producing robust and reliable joints as per hierarchical levels 
and types of cells used to build the battery pack. Relying on the geometry and form factor, lithium-ion cells are manufactured as (i) cylindrical cells; (ii) pouch encased prismatic cell (typically called a pouch cell); and (iii) solid-container encased prismatic cell (typically called a prismatic cell). Choice of joining methods is largely based on the type of cell used, and subsequently, to satisfy electrical, thermal, and mechanical key criteria. This paper identifies major and emerging joining technologies with a comprehensive review and provides guidance for appropriate joining method selection.

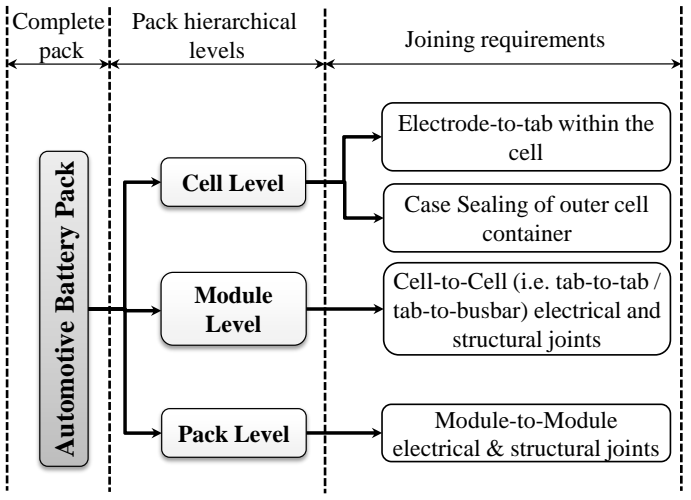

(a)

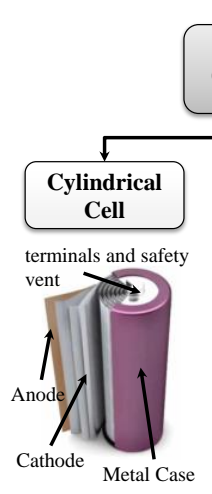

Cathode Metal Case

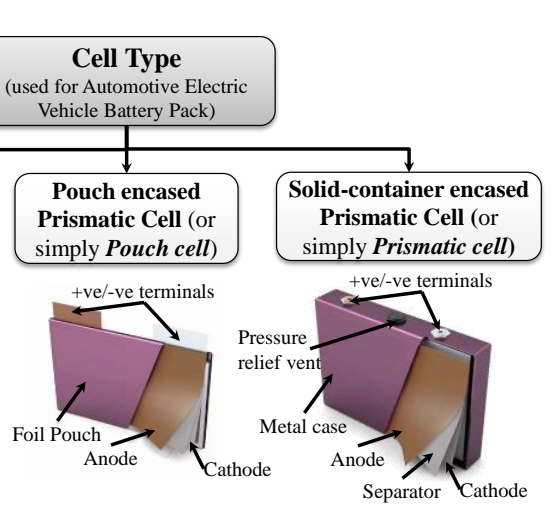

(b)

Figure 1. Battery packs of electric vehicles, and hybrid or plug-in hybrid electric vehicles (EVs/HEVs/PHEVs) (a) joining at hierarchical/assembly levels and (b) cell types [5].

\section{Overview of Key Joining Challenges}

Extensive research has been conducted on developing and characterising Li-ion battery cells including modelling and simulation, material development, performance enhancement, and safety. Limited literature is available on joining preferences and addressing their associated challenges, which can be summarised as follows:

- Electrical and thermal challenges: (i) Producing joints with low electrical resistance-lower electrical resistance at the joint results in low energy loss, low heat generation, and subsequently, lower joint temperature increase during charging and discharging. (ii) Producing joints with low thermal input-low thermal input is preferable, especially when joining with fusion type welding processes, as exposing the cell to high heat may melt or disturb the safety vent, compromise seals, or cause internal shorting. (iii) High thermal fatigue resistance - thermal fatigue resistance of battery interconnects is an important criterion for long-term durability and reliability performance.

- Material and metallurgical challenges: (i) Compatibility for dissimilar materials joining — dissimilar materials may create intermetallic layers, which are not preferred because of their higher electrical resistance and brittle nature compared with parent materials. Therefore, joints with low intermetallic is preferable. (ii) Variability of materials and surfaces-highly conductive and reflective materials, any surface coatings or oxide layers, joint stack-ups (especially varying thicknesses and/or multiple sheets) also need to be overcome for satisfactory joints.

- Mechanical challenges: (i) Durable joint strength—the joint area/nugget size that can be achieved by the joining methods should have satisfactory joint strength with low strength variability. (ii) Avoid mechanical and vibrational damage when joining-excessive deformation of, or transmission of vibration into, the cell may damage internal connection. Precautions must be taken to avoid these as induced residual stress or vibrational energy may be released and cause joint failure. 


\section{Major and Emerging Joining Technologies-A Comprehensive Review}

This section reviews the advantages, disadvantages, limitations, and concerns of major joining technologies (See Table 1) including ultrasonic, resistance spot/projection, micro-Tungsten Inert Gas (TIG) welding/pulsed arc welding, ultrasonic wedge bonding, micro-clinching, magnetic pulse welding, laser welding, and mechanical fastening.

Table 1. Summary of joining technologies.

\begin{tabular}{|c|c|c|c|c|}
\hline Id & Joining Technology & Advantages & Disadvantages & Issues and Concerns \\
\hline 1 & Ultrasonic welding & $\begin{array}{l}\text { Fast process, high strength and } \\
\text { low resistance, able to join } \\
\text { dissimilar materials, low energy } \\
\text { consumption }\end{array}$ & $\begin{array}{l}\text { Only suitable for pouch cells, } \\
\text { two sided access, slow } \\
\text { joining }\end{array}$ & $\begin{array}{l}\text { Access of anvil and sonotrode } \\
\text { needs to be well designed }\end{array}$ \\
\hline 2 & $\begin{array}{l}\text { Resistance } \\
\text { spot/projection welding }\end{array}$ & $\begin{array}{l}\text { Fast process, low cost, good } \\
\text { quality control, easy automation }\end{array}$ & $\begin{array}{l}\text { Difficult for highly } \\
\text { conductive and dissimilar } \\
\text { materials }\end{array}$ & $\begin{array}{l}\text { Difficulty to produce large joints, } \\
\text { joining of more than two layers }\end{array}$ \\
\hline 3 & $\begin{array}{l}\text { Micro-TIG/pulsed arc } \\
\text { welding }\end{array}$ & $\begin{array}{l}\text { Low cost, high joint strength } \\
\text { and low resistance, able to join } \\
\text { dissimilar materials, easy } \\
\text { automation }\end{array}$ & $\begin{array}{l}\text { High thermal input and heat } \\
\text { affected zone, porosity }\end{array}$ & Difficult to join Al to steel \\
\hline 4 & $\begin{array}{l}\text { Ultrasonic wedge } \\
\text { bonding }\end{array}$ & $\begin{array}{l}\text { Fast process, acting as fuses, } \\
\text { able to join dissimilar materials, } \\
\text { low energy consumption and } \\
\text { easy automation }\end{array}$ & $\begin{array}{l}\text { Only suitable for small } \\
\text { wires, low wire and joint } \\
\text { strength }\end{array}$ & $\begin{array}{l}\text { Clamping of the batteries is } \\
\text { critical }\end{array}$ \\
\hline 5 & Micro-Clinching & $\begin{array}{l}\text { Cold process, no additional part, } \\
\text { clean process, able to join } \\
\text { dissimilar materials }\end{array}$ & $\begin{array}{l}\text { Only suitable for pouch cells, } \\
\text { two side access, slow joining }\end{array}$ & $\begin{array}{l}\text { Loosening under vibration, } \\
\text { moisture ingress }\end{array}$ \\
\hline 6 & Soldering & $\begin{array}{l}\text { Joining dissimilar materials, } \\
\text { wide spread in electronics } \\
\text { industry }\end{array}$ & High heat, fluxes required & $\begin{array}{l}\text { Joint strength, debris, } \\
\text { neutralisation of fluxes }\end{array}$ \\
\hline 7 & Laser welding & $\begin{array}{l}\text { High speed, less thermal input, } \\
\text { non-contact process, easy } \\
\text { Automation }\end{array}$ & $\begin{array}{l}\text { High initial cost, additional } \\
\text { shielding system may } \\
\text { required }\end{array}$ & $\begin{array}{l}\text { Need good joint fit-up (intimate } \\
\text { contact), high reflective } \\
\text { materials }\end{array}$ \\
\hline 8 & Magnetic pulse welding & $\begin{array}{l}\text { Solid state process, able to join } \\
\text { dissimilar materials, high joint } \\
\text { strength, dissimilar materials }\end{array}$ & $\begin{array}{l}\text { Potential large distortion, } \\
\text { rigid support required }\end{array}$ & $\begin{array}{l}\text { Possibility of eddy current } \\
\text { passing through the cells }\end{array}$ \\
\hline 9 & Mechanical assembly & $\begin{array}{l}\text { Easy dismounting and recycling, } \\
\text { easy repair, cold process }\end{array}$ & $\begin{array}{l}\text { Additional weight, high } \\
\text { resistance, expensive }\end{array}$ & $\begin{array}{l}\text { Potential mechanical damage } \\
\text { and go loose }\end{array}$ \\
\hline
\end{tabular}

\subsection{Ultrasonic Welding or Ultrasonic Metal Welding (UMW)}

Ultrasonic metal welding (UMW) is one of the most commonly used joining methods for battery systems manufacturing and has been applied to a wide range of metals and thin metal films (e.g., foils). It utilises high frequency ultrasonic vibration, typically $20 \mathrm{kHz}$ or above, to join substrate materials by creating solid-state bonds under a clamping pressure [6]. In principle, high frequency relative motion creates progressive shearing and plastic deformation between mating interfaces and produces an atomic bond at elevated temperature (i.e., typically at 0.3 to 0.5 times the absolute melting temperature of the substrate materials) [7]. However, it needs two sided access, as shown in Figure 2a; one side uses an anvil to support the parts to be joined, and the other side a sonotrode that passes ultrasonic energy to the assembly. Ultrasonic welding is applied for joining of multiple thin foils, dissimilar materials, or highly conductive materials (e.g., $\mathrm{Al}, \mathrm{Cu}$, or others) [8,9], especially for pouch cells [10]. However, it may not be suitable for terminal-to-busbar joints of cylindrical or prismatic cells as vibration under pressure may damage structural integrity. UMW has been used for various EVs/PHEVs, including Nissan LEAF, General Motors Chevrolet-Volt, Spark, and Bolt.

\subsection{Resistance Spot/Projection Welding}

Resistance spot welding (RSW) works on the principle of electrical resistance at the mating surfaces when high current passes through them, creating localised heating and fusion of materials under pressure [11]. Resistance spot welding is used to join different tab materials, up to $0.4 \mathrm{~mm}$ thickness, which are being used for battery connections, including steel, nickel $(\mathrm{Ni})$, copper $(\mathrm{Cu})$, and aluminium (Al) [12]. However, RSW of $\mathrm{Al}$ and $\mathrm{Cu}$ tabs is difficult because of high electric and thermal 
conductivity and in particular, the presence of an oxide layer on the surface of Al. To overcome these challenges, projection welding, a variant of RSW, shows a significant improvement, where projection on tabs will increase the joint quality and make welding easier. As indicated in Figure $2 b$, the projections not only act as energy concentrators for the weld, but also greatly increase electrode lifetimes, because a flat-end RSW-electrode can be used instead of a domed one [13]. In spite of easy automation and good quality control, RSW has challenges when applied to battery welding because of RSW-electrode sticking (i.e., pick-up of material on the electrode tips) [14], highly conductive materials, dissimilar materials having different melting temperatures, and the smaller weld nugget experiencing heat generation during charging-discharging because of the increased current density.
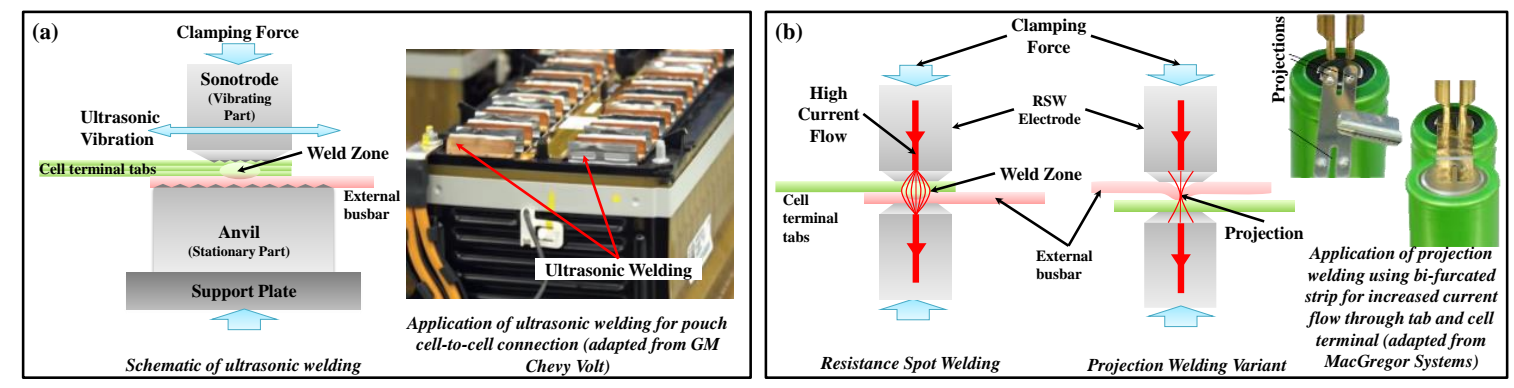

Figure 2. Schematic of working principles and applications: (a) ultrasonic welding and (b) resistance/ projection welding. RSW-resistance spot welding.

\subsection{Micro-TIG or Pulsed Arc Welding (PAW)}

Pulsed arc welding, also known as micro-TIG welding, uses a pulsed TIG arc without filler wire to join thin materials by localised fusion, see Figure 3a [15]. The arc pulse has a very short duration, in tens of milliseconds, such that heat input is much less than in conventional TIG welding, and can be used for welding dissimilar materials [16]. However, even with a significantly reduced heat input, it is still crucial to control the welding parameters to avoid overheating of the battery. PAW is suitable for nickel, copper, or steel tabs and copper bus bars. Al tabs and bus bar joining using PAW is difficult and not preferable (because of the typical direct current (DC)-electrode negative configuration). Alternating current (AC) PAW is more typically used for $\mathrm{Al}$ welding, this is because of the cleaning mechanism, which breaks down the electrically resistive aluminium oxide skin of aluminium alloys. AC pulsed arc welding has not yet been commercially developed for micro-joining applications. For copper tab to copper bus bar welding, micro-TIG can produce a single spot nugget in diameter up to $4 \mathrm{~mm}$. There is no report of the application of pulsed arc welding for joining of existing EV or HEV battery packs.

\subsection{Ultrasonic Wedge Bonding}

Ultrasonic wedge bonding (UWB) is a joining technique typically used for electronic connections between circuit boards or electronic chips [17]. During the welding process, a small (typically $<500 \mu \mathrm{m}$ in diameter) wire (of $\mathrm{Al}, \mathrm{Cu}$, or $\mathrm{Au}$ ) is fed through a welding head; the welding head applies ultrasonic vibration and pressure forcing the wire against the welding target, for example, the battery terminals or bus bar, as shown in Figure $3 \mathrm{~b}$. The main mechanism of UWB is cleaning of mating surfaces and bringing surfaces to the distance required for atomic bonding to create the connections, although other mechanisms, such as inter-diffusion of wire into the mating surface and mechanical interlocking, also contribute to the joining process [18]. UWB can be used for joining of dissimilar materials and the bonded wire can be used as a fuse to protect the battery pack against extreme thermal and mechanical impact or internal defects. However, because transfer of ultrasonic energy into the material to be joined is critical for welding, any significant lateral movement of the welding substrate will be detrimental as it will decrease the vibration amplitude, thereby diminishing the power of the welding operation. Consequently, the cells and the bus bar in the battery module need to be fixed rigidly to allow the 
technology to be applied. In many cases, adhesives or glues have to be used to enhance the rigidity of cells.
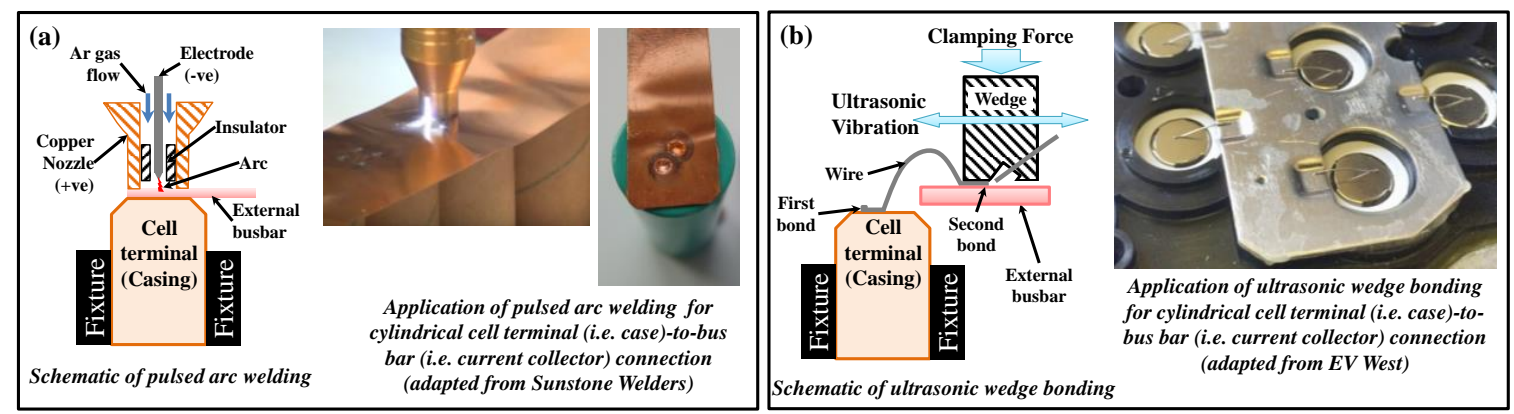

Figure 3. Schematic of working principles and applications of (a) pulsed arc welding and (b) ultrasonic wedge bonding. EV-electric vehicle.

\subsection{Micro-Clinching}

Clinching or micro-clinching is a mechanical interlocking mechanism of sheet metal parts, especially used for automotive body-in-white, domestic appliances, or electronics joining applications [19]. Clinching is a joining process in which a mechanical interlock (i.e., local deformation without use of any additional joining elements) is created by a tooling set (a punch and a die) [20], as shown in Figure 4a. Clinching is a simple technique for point joining of metal sheets typically from $0.2 \mathrm{~mm}$ to $4 \mathrm{~mm}$ thick, to a total joint thickness of about $6 \mathrm{~mm}$. Using the clinching, tab-to-tab joints are feasible. The feasibility of clinching as an alternative method of joining for pouch cell tab joining has been reported. Clinching may not be feasible for cylindrical/prismatic cells joining as access to the both sides of the assembly is required. Further, clinch joints are prone to becoming loose under vibration, moisture ingress, and so on.

\subsection{Soldering}

Joining of dissimilar materials using this method is an established and tested technology within the electronics industry. Soldering of a tab to a terminal of a cylindrical cell may be feasible. Soldering directly to a cell is not recommended as it is easy to melt or disturb the safety vent, compromise seals, or cause internal shorting if the heat is too high (i.e., heat input is the key soldering parameter). Further, it is feasible to solder pouch cell tabs if additional filler metal is used between the tabs. Special aggressive fluxes are required for joining aluminium, which is typically considered unattractive because of the potential for corrosion, reduction of joint strength under vibration, and creating debris. Therefore, soldering is unlikely to be of widespread interest for battery joining applications.

\subsection{Laser Welding}

Laser welding uses a focused laser beam as a point source of energy to create localised heating to join parts together. Because of the small cross section of the laser beam and its energy concentration, narrow and deep welds can be made with a high welding speed [21]. Also, because of the narrow welds and high welding speed, the process generates a low level of heat in the assembly during welding [22], which is important for battery tab welding, as the chemicals inside the batteries are very heat sensitive. A schematic of fillet laser welding and application for prismatic cell-to-bus bar joining are shown in Figure $4 \mathrm{~b}$. When welding a tab to a terminal, generally, the tab should be thinner than the battery cell casing terminal. Process parameters need to be controlled to provide weld strength and conductivity without penetrating the battery case/can. Other applications include sealing of the battery casing for prismatic cells, and joining of tab-to-bus bar and bus bar-to-bus bar [23]. As the weld pool from laser welding is very small, it has a very small gap tolerance, subsequently, during tab 
welding, it may be necessary to clamp the tab to the battery [11]. For oxidisation sensitive materials, such as $\mathrm{Al}$, gas shielding is also required.
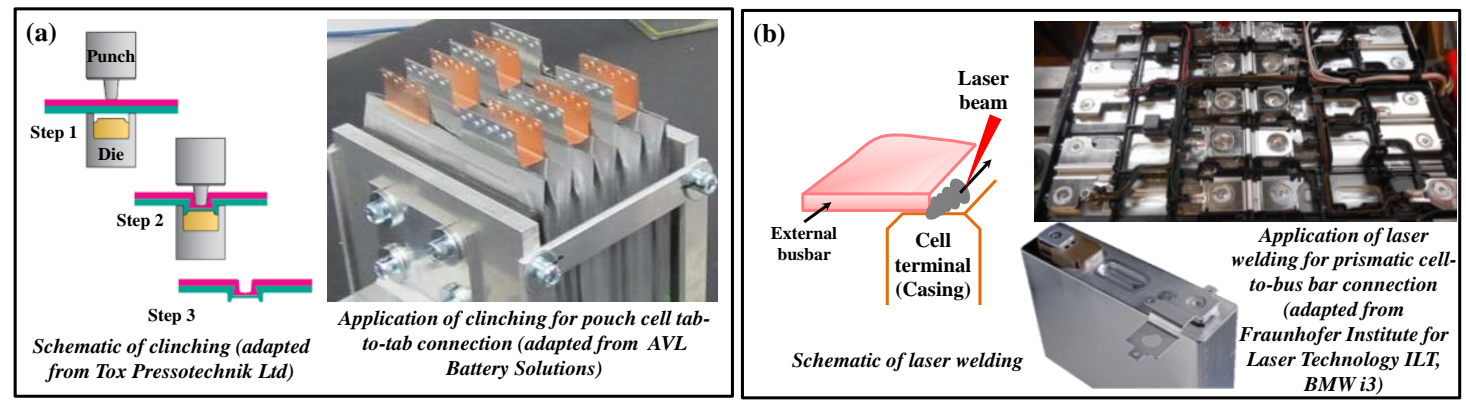

Figure 4. Working principles and applications of (a) clinching and (b) laser welding.

\subsection{Magnetic Pulse Welding (MPW)/Electromagnetic Pulse Technology (EMPT)}

Magnetic pulse welding is a solid state welding process that uses a magnetic pulse to accelerate one part into another, creating a high speed (up to $500 \mathrm{~m} / \mathrm{s}$ ) collision that results in bonding (See Figure $5 \mathrm{a}$ ). The advantages of this process include low heat input, high joint strength, and the capability to join dissimilar materials [24]. However, as the technology has the potential to create an induced current in the cell, because of the pulsed magnetic field necessary for the joining process, damage may occur, which renders it unsuitable for battery joining. However, MPW/EMPT has the potential for joining pouch cell tab-to-tab or tab-to-bus bar [25]. Furthermore, detailed investigation is required as induced eddy currents may affect the electrochemistry/physical parts (e.g., potential cracks or internal joining between current collectors, which lead to battery internal short-circuit) of the pouch cell. To mitigate the risk of damaging the pouch cell or module sensors, a specially designed weld head and shielding plate may be required during welding.
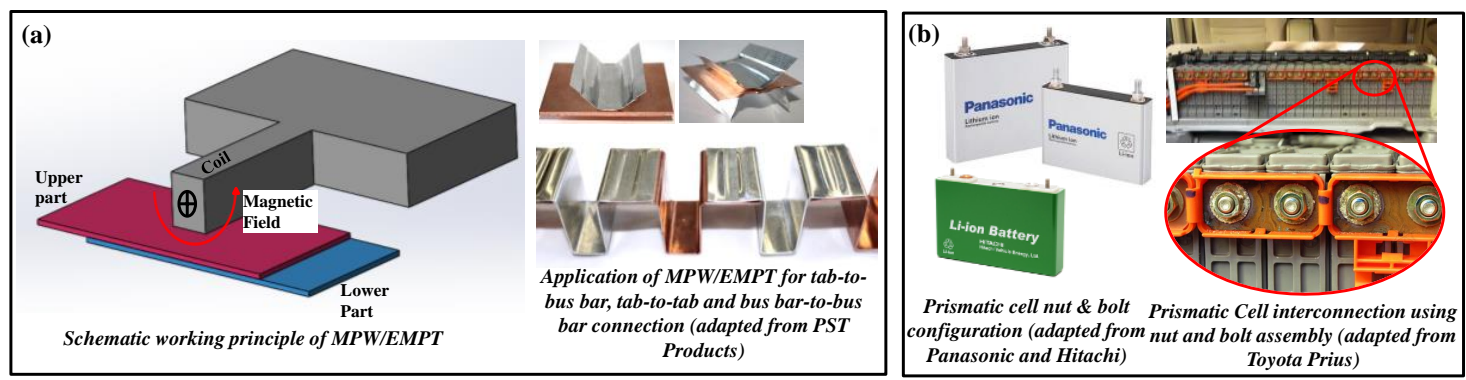

Figure 5. Working principles and applications of (a) magnetic pulse welding/electromagnetic pulse technology (MPW/EMPT) and (b) nut and bolt assembly.

\subsection{Mechanical Assembly}

Various mechanical fastening methods can be used for battery joining, including nut and bolt, spring clasp, screws or snap-fits, and so on [26]. Nut and bolt joints may be either physically distinct nut and bolt assemblies or a threaded feature, for example, electrode and nut. For battery module level connections, nut and bolt joints are mainly limited to prismatic cells, as shown in Figure 5b, and have been used to join electric and hybrid vehicle battery modules. Another example of using mechanical fastening is spring loaded prismatic cells into a custom designed container. Permanent joining, such as welding, may not be suitable for large pack level joining because of battery maintenance and service concerns [13]. Consequently, mechanical nut and bolt assembly has been widely adopted at the pack level. 


\section{Evaluation, Applicability and Feasibility of Joining Technologies}

Continuous advances are being made by battery manufacturers to improve battery pack safety, weight, cost, size, durability, and energy density. Addressing these requirements, this section focuses on cell types and different joining technologies to reflect pack construction and connectivity at their hierarchical levels (i.e., cell, module and pack levels).

\subsection{Battery Pack Hierarchical Joining}

\subsubsection{Joining of Cylindrical Cell Based Battery Pack}

Cylindrical cells consist of a tubular cylindrical can and incorporate safety mechanisms that will interrupt current flow and/or enable venting of gas to avoid overpressure of the can. Cylindrical cells have better thermal management efficiency because of small size, but low packaging efficiency because of their round cross-section. However, their relatively small size results in a large number of cells and connections compared with modules composed of pouch/prismatic cells. The suitability of available joining techniques to build battery packs using cylindrical cells at cell, module or pack levels is described as follows:

- Cell level joining: The assembly process for cylindrical cells requires joining methods at two levels, which are (i) electrode foil-to-tab joining and (ii) terminal welding (i.e., tab-to-case/can). Ultrasonic and resistance spot welding are the most commonly used joining methods for electrode foil-to-tab and terminal welding, respectively [27]. Laser welding is also feasible for electrode foil-to-tab joining, however, tight part-to-part tolerance has to be maintained for satisfactory joints. Terminal welding is not be feasible by laser welding if line of sight is obscured.

- Module and pack level joining: Because of the physical size and form of a cylindrical cell, external current collectors are added to connect cells. Physical projections reduce the contact area in projection welding, allowing concentrated heat generation at the point of contact, and formation of the weld nugget faster and at a lower current level compared with conventional spot welding [28], reducing potential damage to the RSW-electrode. Similar to resistance welding, advances in high-frequency power supplies, increased low-current control, and arc stability, have enabled much finer TIG welding, such as pulsed arc welding. Pulsed arc welding offers excellent copper to copper joining with a fairly relaxed process window with respect to part fit-up and positioning tolerances of the electrode to the parts [29]. As ultrasonic welding exerts high frequency vibration under locally applied force, there is a risk that a cell may suffer internal damage to the electrode. Therefore, ultrasonic welding of cylindrical cells at module level may not be appropriate without steps to mitigate the possibility of damage. However, ultrasonic wedge bonding has been used for cell-to-cell connections. In the Tesla battery pack [30], each of the cells has two wires that act as fuses (one each for the anode and cathode) and are connected using ultrasonic wedge bonding. Laser welding is emerging as an efficient alternative for forming joints between cylindrical cell terminals and external current collectors, that is, bus bars. However, part-to-part fit-up needs to be carefully controlled to achieve satisfactory joints using laser welding. By designing proper jigs and fixtures, a large number of cylindrical cells can be connected to produce a battery module. Permanent joining, such as welding, may not be suitable for large pack level joining because of battery maintenance and service requirements [13]. As a consequence, mechanical nut and bolt assembly has been widely adopted at the pack level.

\subsubsection{Joining of Pouch Cell Based Battery Pack}

In Pouch cells, the internal electrode stack is contained within a soft plastic-aluminium laminate package. Current collectors are welded internally to terminal tabs that protrude through seals to allow external connection [5]. Use of plastic-metal laminates for the cell pouch allows reduction of cell packaging material, higher energy densities, for the same chemistry type (i.e., compared with prismatic 
cells), but typically requires a more complex module structure to constrain the cells. The suitability of joining methods to build battery packs using pouch cells at cell, module, or pack levels can be summarised as follows:

- Cell level joining: During fabrication of pouch cells, the joining operations are (i) electrode current collectors to positive and negative terminal tabs, and (ii) case sealing of pouch cell-an automated and standard process under vacuum [31]. Electrode-to-tab welds are conventionally made using ultrasonic technology because of the need to create a joint through a stack of foils. RSW is not appropriate as RSW-electrodes are prone to picking-up highly conductive cell terminal/electrode and tab materials [32]. However, fibre laser welding technology may be used for increased weld quality and strength [33]. The key to successful application of laser welding is to ensure that (a) the foils are in close contact, and (b) a pulsed laser is used to avoid overheating. In the case of pouch cell case sealing, typically, a compact heat sealer is used to seal aluminium-polymer laminate films.

- Module and pack level joining: Module designs typically position positive and negative terminal tabs either at opposite ends or the same end of the cell based on series or parallel connection requirements. Therefore, the cells are joined either by tab-to-tab or tab-to-bus bar connections. Ultrasonic welding has received significant attention for module level joining as a result of its ability to produce good welds for dissimilar materials and multiple thin layers. RSW or projection welding, pulsed arc welding, and clinching of tab-to-tab or tab-to-bus bar joints are feasible. However, process stability, joint characteristics, thermal input, and process control require further investigation. However, feasible soldering of pouch cell interconnects is not recommended as it raises concerns of joint strength under vibration, neutralisation of fluxes, risk of localised heat damage, and creation of debris in the joint area. As an alternative, MPW/EMPT has the potential for joining pouch cell tab-to-tab or tab-to-bus bar [25]. However, detailed investigation is required for MPW/EMPT application, as induced eddy currents may affect the physical parts/electrochemistry (e.g., potential cracks or internal joining between current collectors that leads to battery internal short-circuit) of the pouch cell. To mitigate the risk of damaging the pouch cell, or module sensors, a specially designed weld head and shielding plate may be required during EMPT welding. Laser welding is another alternative solution for pouch cell tab-to-tab or tab-to-bus bar joining. Fibre lasers are able to weld many material combinations including aluminium to aluminium, aluminium to steel, copper to steel, and copper to aluminium. Further investigations are required for fixture design, process parameter optimisation and process control. Generally, pack level (i.e., module-to-module) connections are made with mechanical fasteners.

\subsubsection{Joining of Prismatic Cell Based Battery Pack}

Aluminium or steel cans are typically used for the housing of solid container-encased prismatic lithium-ion cells, more commonly called prismatic cells. The metal can ensure structural stability, mechanical robustness, and humidity protection. In addition, it allows for the use of safety features such as pressure relief vents, which are not possible in pouch cells. In some cases, prismatic cells may allow packaging to be more efficient than cylindrical cells because of their form factor [5]. The suitability of available joining methods to build battery packs using prismatic cells at cell, module, or pack levels is described as follows:

- Cell level joining: The fabrication of prismatic cells involves similar joining operations to cylindrical and pouch cells (i) between current collector tabs and electrode foil(s), (ii) between collector tab and battery terminal, and (iii) case sealing. Ultrasonic welding is most commonly used for joining current collector tabs with electrode foil(s) [31]. Resistance spot welding is used to connect current collector tabs with the case or with the top cap of the case [27]. Typically, prismatic cell positive and negative terminals are based on mechanical nut and bolt assembly. Laser welding is also used for cell level joining and traditionally case sealing. As reported by Shannon [12], 
laser welding has potential for a number of manufacturing applications, such as case sealing [34] and terminal welding.

- Module and pack level joining: As a result of the stackable form of prismatic cells, battery pack modularity and various design configurations for parallel or series connections are readily achievable. Module and pack level joining is mainly performed with mechanical nut and bolt fasteners or clip fitting. Mechanical nut and bolt assembly has the advantage of easy disassembly and higher joint strength compared with other reported joining techniques. However, there are issues with high contact resistance and maximum torque (to avoid internal damage) that can be sustained by the cell stud. In some cases, laser welding has also been used for connecting cell terminal with bus bar [35]. Ultrasonic wedge bonding and micro-TIG between terminal and bus bar may be feasible for prismatic cells. However, design changes may be required for UWB since cell terminals are not directly connected with bus bars. Application of these methods requires investigation of wire thickness, heat input, current carrying capacity, and so on.

\subsection{Joining Technology Recommendation for Battery Manufacturing}

This section maps joining technologies with manufacturing readiness levels (MRLs) to indicate options and development status of battery joining from a manufacturing perspective (as illustrated in Figure 6). Manufacturing readiness levels (MRLs) are used to provide a relative measure of technology maturity, risk level, and extent of application. Ultrasonic welding, ultrasonic wedge bonding, and mechanical assembly are frequently used in battery pack manufacturing (used by battery manufacturers, original equipment manufacturers, and tier 1 suppliers) and have been demonstrated at the highest level of production (MRLs 8-10). RSW, micro-TIG, micro-clinching, and soldering have demonstrated their capability under laboratory conditions (MRL 4) to produce joints for low or batch volume during module manufacture (MRL 6/7). In contrast, laser welding exhibits a broad range of capability from MRL 4 to MRL 10. For example, laser welding applications for module level joining of cylindrical or pouch cells are in MRL 4-6, whereas laser applications for case sealing or module level joining of prismatic cells have been demonstrated at MRL 10. Another joining technology, MPW/EMPT, has a low MRL as it has only demonstrated limited capability under laboratory conditions to produce tab-to-tab joining. Recommendations for further investigation are given in Table 2.

Table 2. Recommendations for further investigation based on manufacturing readiness levels (MRLs). RSW—resistance spot welding; MWP/EMPT—magnetic pulse welding/electromagnetic pulse technology.

\begin{tabular}{lccc}
\hline \multicolumn{1}{c}{ Module Level Joining } & \multicolumn{3}{c}{ MRL } \\
\cline { 2 - 4 } & Low (1-3) & Medium (4-6) & High (7-10) \\
\hline Investigate pouch module level joining & MPW/EMPT & \\
\hline $\begin{array}{l}\text { Cylindrical and pouch module level, } \\
\text { further extend to prismatic module level }\end{array}$ & & Laser Welding, \\
\hline $\begin{array}{l}\text { Cylindrical module level, further extend to } \\
\text { prismatic module level }\end{array}$ & Micro-TIG, RSW & \\
\hline
\end{tabular}

The Pugh matrix has been employed to evaluate different technologies that are suitable for joining cylindrical, pouch, and prismatic cell types, identifying technologies that are likely to be feasible and have favourable risk/benefit characteristics. It is a scoring matrix used for concept selection in which technology options are assigned scores relative to their fulfilment of explicit criteria. The Pugh matrix in Figure 7 identifies three joining technologies, ultrasonic wedge bonding, laser welding (highlighted as "green" as they are in production), and micro-TIG (highlighted as "amber" as it has potential for production application), that would merit further investigation for cylindrical cell battery pack manufacturing. Figure 8 shows current and potential candidates for pouch cell based battery packs, namely, ultrasonic welding, laser welding, micro-TIG, and clinching. Figure 9 
demonstrates that mechanical assembly, laser welding, micro-TIG, and ultrasonic wedge bonding have potential for industrial application and warrant further investigation for prismatic cell based battery pack manufacturing.

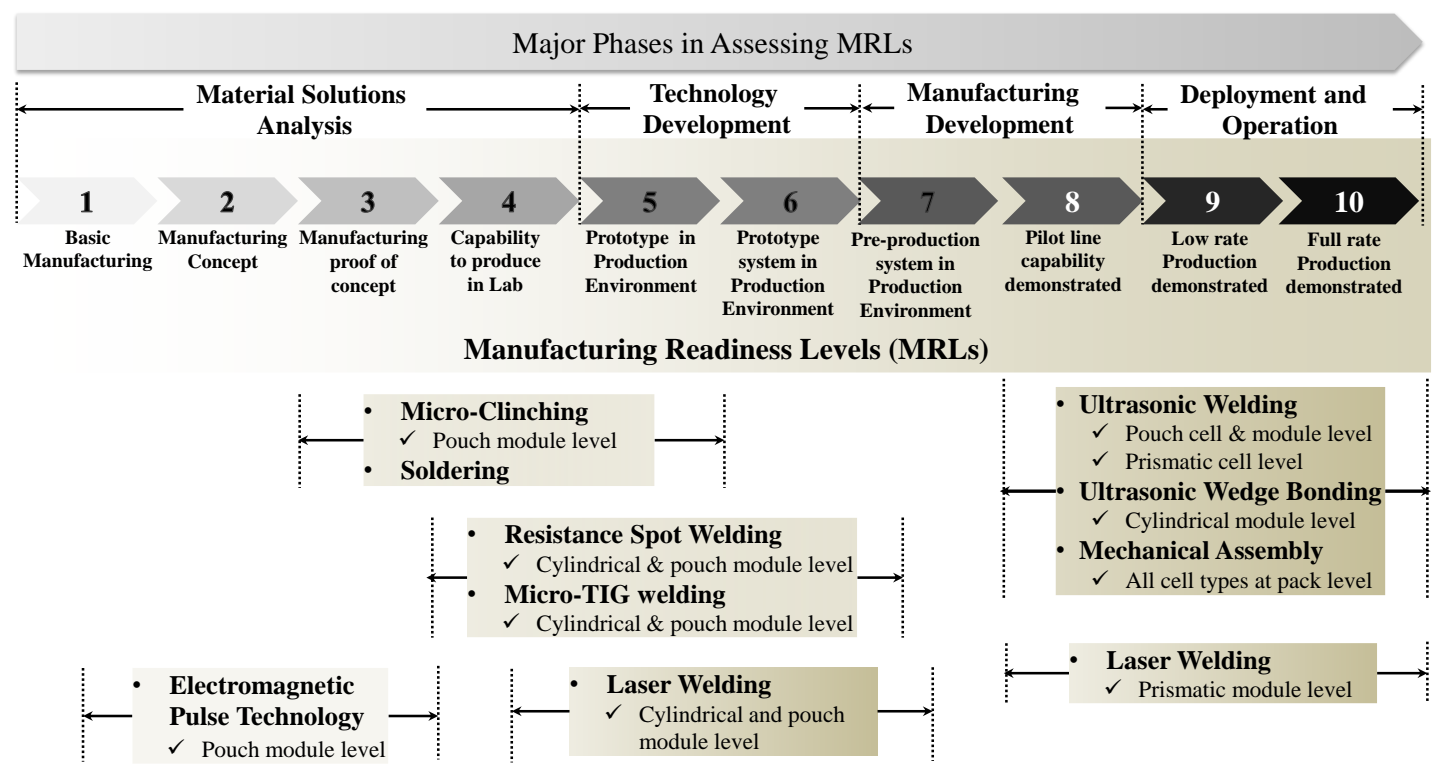

Figure 6. MRLs for assessing technology maturity of current joining technologies for module level joining (e.g., terminal-to-tab, tab-to-tab, or tab-to-bus bar).

\begin{tabular}{|c|c|c|c|c|c|c|c|}
\hline \multirow[b]{2}{*}{ Factor } & \multirow[b]{2}{*}{ Weight } & \multicolumn{6}{|c|}{ Joining technologies - Cyclindrical Cell } \\
\hline & & $\begin{array}{c}\text { Resistance spot } \\
\text { welding/ Projection } \\
\text { Welding }\end{array}$ & $\begin{array}{c}\text { Micro-TIG } \\
\text { Welding/ Pulsed } \\
\text { Arc Welding }\end{array}$ & $\begin{array}{c}\text { Ultrasonic wedge } \\
\text { bonding }\end{array}$ & Laser welding & Soldering & $\begin{array}{c}\text { Mechanical } \\
\text { joining }\end{array}$ \\
\hline Total & & 377 & 397 & 403 & 390 & 352 & 348 \\
\hline \multicolumn{8}{|l|}{ Joint resistance } \\
\hline Joint resistance-similar materials & 5 & 4 & 4 & 4 & 5 & 5 & 2 \\
\hline Joint resistance-dissimilar materials & 5 & 2 & 4 & 5 & 3 & 5 & 2 \\
\hline \multicolumn{8}{|l|}{ Joint strength } \\
\hline Joint strength-similar materials & 3 & 4 & 4 & 3 & 5 & 3 & 5 \\
\hline Joint strength-dissimilar materials & 3 & 1 & 3 & 2 & 3 & 3 & 5 \\
\hline Heat transfer from process & 5 & 3 & 3 & 5 & 4 & 1 & 5 \\
\hline Potential mechanical damage & 5 & 4 & 4 & 4 & 5 & 5 & 2 \\
\hline Joint current capacity & 5 & 3 & 3 & 2 & 5 & 4 & 5 \\
\hline Joint durability & 5 & 4 & 4 & 3 & 4 & 4 & 3 \\
\hline Potential vibration damage & 5 & 5 & 5 & 4 & 5 & 5 & 5 \\
\hline Joint corrosion resistance & 4 & 4 & 4 & 5 & 4 & 2 & 2 \\
\hline In process quality control & 5 & 4 & 4 & 5 & 2 & 2 & 3 \\
\hline Cycle time & 4 & 4 & 4 & 4 & 5 & 2 & 1 \\
\hline Sensitivity & 4 & 4 & 4 & 5 & 4 & 3 & 5 \\
\hline Repeatability & 4 & 3 & 4 & 4 & 4 & 4 & 5 \\
\hline Cost per battery connection & 4 & 5 & 5 & 4 & 4 & 3 & 2 \\
\hline Investment & 3 & 4 & 4 & 4 & 2 & 5 & 5 \\
\hline Easy recycling & 2 & 2 & 2 & 2 & 2 & 2 & 5 \\
\hline Easy automation & 5 & 4 & 4 & 5 & 5 & 1 & 1 \\
\hline Delivery time & 3 & 4 & 4 & 4 & 3 & 5 & 3 \\
\hline Standard Equipment & 3 & 3 & 3 & 5 & 3 & 5 & 3 \\
\hline Flexibility ie easy to adapt & 3 & 3 & 3 & 2 & 3 & 5 & 4 \\
\hline Used for similar applications elsewhere & 4 & 4 & 4 & 5 & 3 & 1 & 2 \\
\hline Safety & 5 & 4 & 4 & 4 & 3 & 4 & 5 \\
\hline Cost of ownership & 2 & 5 & 5 & 3 & 4 & 5 & 5 \\
\hline Technique support & 5 & 5 & 5 & 4 & 4 & 4 & 4 \\
\hline
\end{tabular}

Figure 7. Pugh matrix for evaluation of joining methods for manufacturing of cylindrical cell based module. 


\begin{tabular}{|c|c|c|c|c|c|c|c|c|}
\hline \multirow[b]{2}{*}{ Factor } & \multirow[b]{2}{*}{ Weight } & \multicolumn{7}{|c|}{ Joining technologies - Pouch Cell } \\
\hline & & $\begin{array}{c}\text { Ultrasonic } \\
\text { Welding }\end{array}$ & $\begin{array}{c}\text { Resistance Spot } / \\
\text { Projection } \\
\text { Welding }\end{array}$ & $\begin{array}{l}\text { Micro-TiG / } \\
\text { Pulsed Arc } \\
\text { Welding }\end{array}$ & $\begin{array}{c}\text { Laser } \\
\text { welding }\end{array}$ & Clinching & Soldering & $\begin{array}{c}\text { Mechanical } \\
\text { Assembly (Nut } \\
\& \text { bolt) }\end{array}$ \\
\hline Total & & 413 & 359 & 379 & 401 & 361 & 357 & 356 \\
\hline \multicolumn{9}{|l|}{ Joint resistance } \\
\hline Joint resistance-similar materials & 5 & 4 & 4 & 5 & 5 & 4 & 5 & 2 \\
\hline Joint resistance-dissimilar materials & 5 & 5 & 1 & 4 & 3 & 5 & 5 & 2 \\
\hline \multicolumn{9}{|l|}{ Joint strength } \\
\hline Joint strength-similar materials & 3 & 4 & 4 & 4 & 5 & 3 & 3 & 5 \\
\hline Joint strength-dissimilar materials & 3 & 3 & 1 & 3 & 3 & 3 & 3 & 5 \\
\hline Heat transfer from process & 5 & 4 & 3 & 3 & 4 & 5 & 2 & 5 \\
\hline Potential mechanical damage & 5 & 5 & 5 & 5 & 5 & 4 & 5 & 2 \\
\hline Joint current capacity & 5 & 5 & 2 & 2 & 5 & 3 & 4 & 5 \\
\hline Joint durability & 5 & 4 & 4 & 4 & 4 & 2 & 4 & 3 \\
\hline Potential vibration damage during welding & 5 & 3 & 5 & 5 & 5 & 5 & 5 & 5 \\
\hline Joint corrosion resistance & 4 & 4 & 3 & 3 & 4 & 4 & 2 & 2 \\
\hline In process quality control & 5 & 4 & 4 & 4 & 2 & 3 & 2 & 3 \\
\hline Cycle time & 4 & 4 & 4 & 3 & 5 & 2 & 2 & 1 \\
\hline Sensitivity & 4 & 5 & 3 & 3 & 4 & 4 & 3 & 5 \\
\hline Repeatability & 4 & 4 & 4 & 4 & 4 & 4 & 4 & 4 \\
\hline Cost per battery connection & 4 & 5 & 5 & 5 & 4 & 4 & 3 & 2 \\
\hline Investment & 3 & 4 & 4 & 5 & 2 & 5 & 5 & 5 \\
\hline Easy recycling & 2 & 2 & 2 & 2 & 2 & 4 & 2 & 5 \\
\hline Easy automation & 5 & 4 & 4 & 4 & 5 & 3 & 1 & 1 \\
\hline Delivery time & 3 & 4 & 4 & 4 & 3 & 3 & 5 & 5 \\
\hline Standard Equipment & 3 & 4 & 4 & 4 & 4 & 3 & 5 & 5 \\
\hline Flexibility i.e. easy to adapt & 3 & 2 & 3 & 3 & 3 & 3 & 5 & 4 \\
\hline Used for similar applications elsewhere & 4 & 5 & 2 & 2 & 5 & 3 & 1 & 2 \\
\hline Safety & 5 & 4 & 4 & 3 & 3 & 3 & 4 & 5 \\
\hline Cost of ownership & 2 & 4 & 3 & 3 & 4 & 4 & 5 & 5 \\
\hline Technique support & 5 & 4 & 5 & 5 & 4 & 4 & 4 & 4 \\
\hline
\end{tabular}

Figure 8. Pugh matrix for evaluation of joining methods for manufacturing of pouch cell based module.

\begin{tabular}{|c|c|c|c|c|c|c|}
\hline \multirow[b]{2}{*}{ Factor } & \multirow[b]{2}{*}{ Weight } & \multicolumn{5}{|c|}{ Joining technologies - Prismatic Cell } \\
\hline & & $\begin{array}{c}\text { Ultrasonic } \\
\text { Wedge Bonding }\end{array}$ & $\begin{array}{c}\text { Micro-TIG } \\
\text { Welding/ Pulsed } \\
\text { Arc Welding }\end{array}$ & $\begin{array}{c}\text { Resistance spot / } \\
\text { Projection } \\
\text { Welding }\end{array}$ & $\begin{array}{c}\text { Laser } \\
\text { welding }\end{array}$ & $\begin{array}{c}\text { Mechanical } \\
\text { Assembly } \\
\text { (Nut \& bolt) }\end{array}$ \\
\hline Total & & 389 & 380 & 367 & 398 & 381 \\
\hline \multicolumn{7}{|l|}{ Joint resistance } \\
\hline Joint resistance-similar materials & 5 & 4 & 4 & 4 & 5 & 2 \\
\hline Joint resistance-dissimilar materials & 5 & 5 & 4 & 2 & 3 & 2 \\
\hline \multicolumn{7}{|l|}{ Joint strength } \\
\hline Joint strength-similar materials & 3 & 3 & 4 & 4 & 5 & 5 \\
\hline Joint strength-dissimilar materials & 3 & 3 & 3 & 1 & 3 & 5 \\
\hline Heat transfer from process & 5 & 5 & 3 & 3 & 4 & 5 \\
\hline Potential mechanical damage & 5 & 4 & 4 & 4 & 5 & 2 \\
\hline Joint current capacity & 5 & 1 & 2 & 2 & 5 & 5 \\
\hline Joint durability & 5 & 3 & 4 & 4 & 4 & 3 \\
\hline Potential vibration damage & 5 & 4 & 5 & 5 & 5 & 5 \\
\hline Joint corrosion resistance & 4 & 5 & 4 & 4 & 4 & 2 \\
\hline In process quality control & 5 & 5 & 4 & 4 & 2 & 3 \\
\hline Cycle time & 4 & 4 & 4 & 4 & 5 & 1 \\
\hline Sensitivity & 4 & 5 & 4 & 4 & 4 & 5 \\
\hline Repeatability & 4 & 4 & 4 & 4 & 4 & 5 \\
\hline Cost per battery connection & 4 & 4 & 5 & 5 & 4 & 3 \\
\hline Investment & 3 & 4 & 4 & 4 & 2 & 5 \\
\hline Easy recycling & 2 & 2 & 2 & 2 & 2 & 5 \\
\hline Easy automation & 5 & 5 & 4 & 4 & 5 & 1 \\
\hline Delivery time & 3 & 4 & 4 & 4 & 3 & 5 \\
\hline Standard Equipment & 3 & 5 & 3 & 4 & 3 & 5 \\
\hline Flexibility ie easy to adapt & 3 & 2 & 3 & 3 & 3 & 4 \\
\hline Used for similar applications elsewhere & 4 & 2 & 1 & 1 & 5 & 5 \\
\hline Safety & 5 & 4 & 4 & 4 & 3 & 5 \\
\hline Cost of ownership & 2 & 3 & 5 & 5 & 4 & 5 \\
\hline Technique support & 5 & 4 & 5 & 5 & 4 & 5 \\
\hline
\end{tabular}

Figure 9. Pugh matrix for evaluation of joining methods for manufacturing of pouch cell based module. 


\section{Conclusions}

This paper focuses on the applicability of joining technologies for automotive battery system manufacturing. It identifies and reviews suitable joining technologies based on battery pack construction and connectivity requirements for the dominant cell types in use.

- Cylindrical, pouch, and prismatic cells based battery pack construction are discussed in detail, with limitations of the specific technologies identified where their use is infeasible. Further, applicability of joining methods is discussed with hierarchical levels of battery manufacturing.

- Key joining challenges are identified for battery systems manufacture, including electrical, thermal, material, metallurgical, and mechanical challenges.

- Joining techniques are described with respect to MRLs and suitability of the identified joining technologies is quantified. Recommendations for further investigation of joining technologies are made based on Pugh matrix scores, MRLs, and application potential.

Author Contributions: Formal analysis, A.D.; Funding acquisition, D.G.; Investigation, A.D. and D.L.; Methodology, A.D.; Project administration, D.W. and D.G.; Resources, D.G.; Supervision, D.W.; Writing-original draft, A.D.; Writing一review \& editing, D.W.

Funding: This research has been supported by EPSRC Institutional Grant for the APC Spoke and WMG Centre High Value Manufacturing (HVM) Catapult.

Conflicts of Interest: The authors declare no conflict of interest.

\section{References}

1. Faria, R.; Moura, P.; Delgado, J.; de Almeida, A.T. A Sustainability Assessment of Electric Vehicles as a Personal Mobility System. Energy Convers. Manag. 2012, 61, 19-30. [CrossRef]

2. Whittingham, M.S. History, Evolution, and Future Status of Energy Storage. Proc. IEEE 2012, 100, $1518-1534$. [CrossRef]

3. Becker, J.; Nemeth, T.; Wegmann, R.; Sauer, D. Dimensioning and Optimization of Hybrid Li-Ion Battery Systems for EVs. World Electr. Veh. J. 2018, 9, 19. [CrossRef]

4. Pfriem, M.; Gauterin, F. Development of Real-World Driving Cycles for Battery Electric Vehicles. World Electr. Veh. J. 2016, 8, 14-24. [CrossRef]

5. JMBS. Our Guide to Batteries; Johnson Matthey Battery Systems: Milton Keynes, UK, 2015.

6. Zhang, C.; Li, L. A Coupled Thermal-Mechanical Analysis of Ultrasonic Bonding Mechanism. Metall. Mater. Trans. B 2009, 40, 196-207. [CrossRef]

7. De Vries, E. Mechanics and Mechanisms of Ultrasonic Metal Welding; The Ohio State University: Columbus, $\mathrm{OH}, \mathrm{USA}, 2004$.

8. Siddiq, A.; Ghassemieh, E. Thermomechanical Analyses of Ultrasonic Welding Process Using Thermal and Acoustic Softening Effects. Mech. Mater. 2008, 40, 982-1000. [CrossRef]

9. Kim, T.H.; Yum, J.; Hu, S.J.; Spicer, J.P.; Abell, J.A. Process Robustness of Single Lap Ultrasonic Welding of Thin, Dissimilar Materials. CIRP Ann.-Manuf. Technol. 2011, 60, 17-20. [CrossRef]

10. Shawn Lee, S.; Hyung Kim, T.; Jack Hu, S.; Cai, W.W.; Abell, J.A.; Li, J. Characterization of Joint Quality in Ultrasonic Welding of Battery Tabs. J. Manuf. Sci. Eng. 2013, 135, 021004. [CrossRef]

11. Brand, M.J.; Schmidt, P.A.; Zaeh, M.F.; Jossen, A. Welding Techniques for Battery Cells and Resulting Electrical Contact Resistances. J. Energy Storage 2015, 1, 7-14. [CrossRef]

12. Shannon, G. Improve Tab to Terminal Connections in Battery Pack Manufacturing; Amada Miyachi America Inc.: Monrovia, CA, USA, 2016.

13. Lee, S.S.; Kim, T.H.; Hu, S.J.; Cai, W.W.; Abell, J.A. (Eds.) Joining Technologies for Automotive Lithium-Ion Battery Manufacturing: A Review. In Proceedings of the ASME 2010 International Manufacturing Science and Engineering Conference, Erie, PA, USA, 12-15 October 2010.

14. Zhou, Y.; Gorman, P.; Tan, W.; Ely, K.J. Weldability of Thin Sheet Metals During Small-Scale Resistance Spot Welding Using an Alternating-Current Power Supply. J. Electr. Mater. 2000, 29, 1090-1099. [CrossRef]

15. Park, M.; Hirata, Y. Research on Generation of Micro-Plasma Arc and Its Power Intensity. Weld. Int. 2017, 31, 284-290. [CrossRef] 
16. Hirata, Y. Pulsed Arc Welding. Weld. Int. 2003, 17, 98-115. [CrossRef]

17. Ji, H.; Li, M.; Wang, C.; Guan, J.; Bang, H.S. Evolution of the Bond Interface During Ultrasonic Al-Si Wire Wedge Bonding Process. J. Mater. Process. Technol. 2007, 182, 202-206. [CrossRef]

18. Lum, I.; Mayer, M.; Zhou, Y. Footprint Study of Ultrasonic Wedge-Bonding with Aluminum Wire on Copper Substrate. J. Electron. Mater. 2006, 35, 433-442. [CrossRef]

19. Balawender, T.; Sadowski, T.; Kneć, M. Technological Problems and Experimental Investigation of Hybrid: Clinched-Adhesively Bonded Joint. Arch. Metall. Mater. 2011, 56, 438-446. [CrossRef]

20. Varis, J. Ensuring the Integrity in Clinching Process. J. Mater. Process. Technol. 2006, 174, 277-285. [CrossRef]

21. Walsh, C. Laser Welding_Literature Review; University of Cambridge: Cambridge, UK, 2002.

22. Steen, W.M.; Mazumder, J. Laser Welding. In Laser Material Processing; Steen, W.M., Mazumder, J., Eds.; Springer: London, UK, 2010; pp. 199-249.

23. Schmalen, P.; Plapper, P.; Cai, W. Process Robustness of Laser Braze-Welded Al/Cu Connectors. SAE Int. J. Altern. Power 2016, 5, 195-204. [CrossRef]

24. Schäfer, R.; Pasquale, P.; Elsen, A. (Eds.) Material Hybrid Joining of Sheet Metals by Electromagnetic Pulse Technology. In Key Engineering Materials; Trans Tech Publications: Zürich, Switzerland, 2011.

25. Kashani, M. Application of Magnetic Pulse Welding in Lithium-Ion Batteries Production; Tokyo Metropolitan College of Technology: Tokyo, Japan, 2014.

26. Bonenberger, P.R. The First Snap-Fit Handbook, 3rd ed.; Hanser: Munich, Germany, 2016; pp. I-XXII.

27. Tagawa, K.; Brodd, R.J. Production Processes for Fabrication of Lithium-Ion Batteries. In Lithium-Ion Batteries: Science and Technologies; Yoshio, M., Brodd, R.J., Kozawa, A., Eds.; Springer: New York, NY, USA, 2009; pp. 181-194.

28. Sun, X. Effect of Projection Height on Projection Collapse and Nugget Formation-A Finite Element Study. Weld. J. 2001, 80, 211s-216s.

29. Shannon, G. Selecting, Applying the Right Technology for Welding Batteries. 2014. Available online: http:// weldingdesign.com/operations / selecting-applying-right-technology-welding-batteries?page=3 (accessed on 13 December 2016).

30. Berdichevsky, G.; Kelty, K.; Straubel, J.; Toomre, E. The Tesla Roadster Battery System; Tesla Motors: Palo Alto, CA, USA, 2006.

31. Reinhart, G.; Zeilinger, T.; Kurfer, J.; Westermeier, M.; Thiemann, C.; Glonegger, M.; Wunderer, M.; Tammer, C.; Schweier, M.; Heinz, M. Research and Demonstration Center for the Production of Large-Area Lithium-Ion Cells; Springer: Berlin/Heidelberg, Germany, 2013; pp. 3-12.

32. Dong, S.; Kelkar, G.; Zhou, Y. Electrode Sticking During Micro-Resistance Welding of Thin Metal Sheets. IEEE Trans. Electron. Packag. Manuf. 2002, 25, 355-361. [CrossRef]

33. Shannon, G. Battery Welding: Using Lasers for Tab Welding Applications. Amada Miyachi Blog, 2015. Available online: http:/ /info.amadamiyachi.com/blog/laser-welding-tabs-for-battery-pack-manufacture (accessed on 13 December 2016).

34. Mikolajczak, C.; Kahn, M.; White, K.; Long, R.T. Lithium-Ion. Batteries Hazard and Use Assessment; Springer Science \& Business Media: Berlin/Heidelberg, Germany, 2012.

35. Automotive Battery-Battery Module I Samsung Sdi. Available online: http://www.samsungsdi.com/ automotive-battery/products/battery-module.html (accessed on 22 December 2016).

(C) 2018 by the authors. Licensee MDPI, Basel, Switzerland. This article is an open access article distributed under the terms and conditions of the Creative Commons Attribution (CC BY) license (http:/ / creativecommons.org/licenses/by/4.0/). 